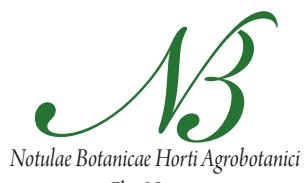

Cluj-Napoca

\title{
Influence of Variability of Ryegrass Meadow Soil Conditions on their Natural and Utilization Values
}

\author{
Anna KRYSZAK, Agnieszka KLARZYŃSKA, Jan KRYSZAK, \\ Agnieszka STRYCHALSKA, Łukasz MAĆKOWIAK \\ Poznan University of Life Sciences, Department of Grassland and Natural Landscape \\ Sciences,Dojazd 11,60-632Poznań,Poland; agaklar@up.poznan.pl
}

\begin{abstract}
The study presents the findings of research into the effect of the variability of site conditions on their floristic composition providing a basis for the identification of lower phytosociological units. Patches of Arrhenatheretum elatioris described with the assistance of phytosociological surveys conducted using the Braun-Blanquet method were subjected to multi-criteria evaluation. On their basis, the following parameters were determined: ecological and botanical structure, geographic-historical distribution, the structure of the lifegroups of the floristic types identified, as well as natural values by the Oświt method and sward fodder value according to Filipek. In order to determine the causes of the floristic variability observed, the following soil conditions were assessed: moisture content, soil reaction and nitrogen content by Ellenberg's indicator method, as well as potassium, magnesium and phosphorus content by the appropriate laboratory methods. Typical forms of Arrhenatheretum elatioris phytocenoses were found to develop on mucky soils in moderately moist sites. Patches of ryegrass occurring in sites with a periodically higher moisture content on organic soils refer to the Alopecuretum pratensis association. On the other hand, the sward of ryegrass meadows developed on dryer, mineral soils was characterised by increased numbers of species characteristic for xerothermic swards from the Festuco-Brometea class and sandy plant communities from the Koelerio glaucaCorynephoretea canescentis. More intensive utilization, primarily-fertilisation, was among the causes of the development of species-poor phytocenoses of low natural value but sward of a good fodder value.
\end{abstract}

Keywords: Arrhenatheretum elatioris, floristic diversity, natural value, soil conditions, utilization value

\section{Introduction}

Arrhenatheretum elatioris are among the most widespread plant communities in Poland and in Central Europe as a whole (Dierschke, 1994, 1999a; Duchoslav, 1997; Kojić et al., 2005; Kucharski and Michalska-Hejduk, 1994; Mucina et al., 1993; Rozbrojová et al., 2010; Valev et al., 2011; Zarzycki et al., 2011; Żyszkowska, 2007). This can be attributed mainly to the wide ecological scale of species making up this phytocenosis. This is reflected in the recorded sub-associations (Kryszak, 2001; Kucharski, 1999; Sykora et. al., 1990). Typically developed patches of Arrhenatheretum elatioris possess a characteristic multilayer structure with a majority of tall grasses, including dominant oat grass (Arrhenatherum elatius (L.) P. Beauv. ex J. Presl and C. Presl), as well as numerous legumes and other dicotyledonous perennials. This is a community which, on typical sites found on moderately moist and relatively fertile soils and at extensive utilization, is characterized by exceptionally high biological diversity, which is expressed in the high landscape value of these meadows. In the course of the last 20 years, however, the gradual disappearance of meadows developed in a typical form has been observed (Vintu et al., 2011; Weigelt et al., 2009). The current structure of Arrhenatheretum elatioris patches was affected, first and foremost, by changes in utilization: on one hand, intensification, where the demand for forages was high and, in other places, the decline in the utilization of meadows which were sometimes left idle for some years, and on the other hand, the floristic structure of ryegrass meadows is associated with site conditions (Zarzycki et al., 2011). The significant drying out of river valleys and flooding, which had previously not been observed, were quickly reflected in the structure of the plant cover.

The aim of this study was to assess the impact of soil conditions on the diversity of Arrhenatheretum elatioris in: floristic compositions, which formed the basis for division of lower syntaxonomic units (1) and in natural and utilizations values (2).

\section{Material and methods}

Multifaceted analysis was carried out on 300 phytosociological reléves of the Arrhenatheretum elatioris association recorded using the Braun-Blanquet scale (Szafer and Zarzycki, 1977) on lowland areas of Wielkopolska Region (Poland) (Fig.1) between 2008-2010 and uploaded to the TURBOVEG database, where they were subjected to edition and initial numerical classification. 


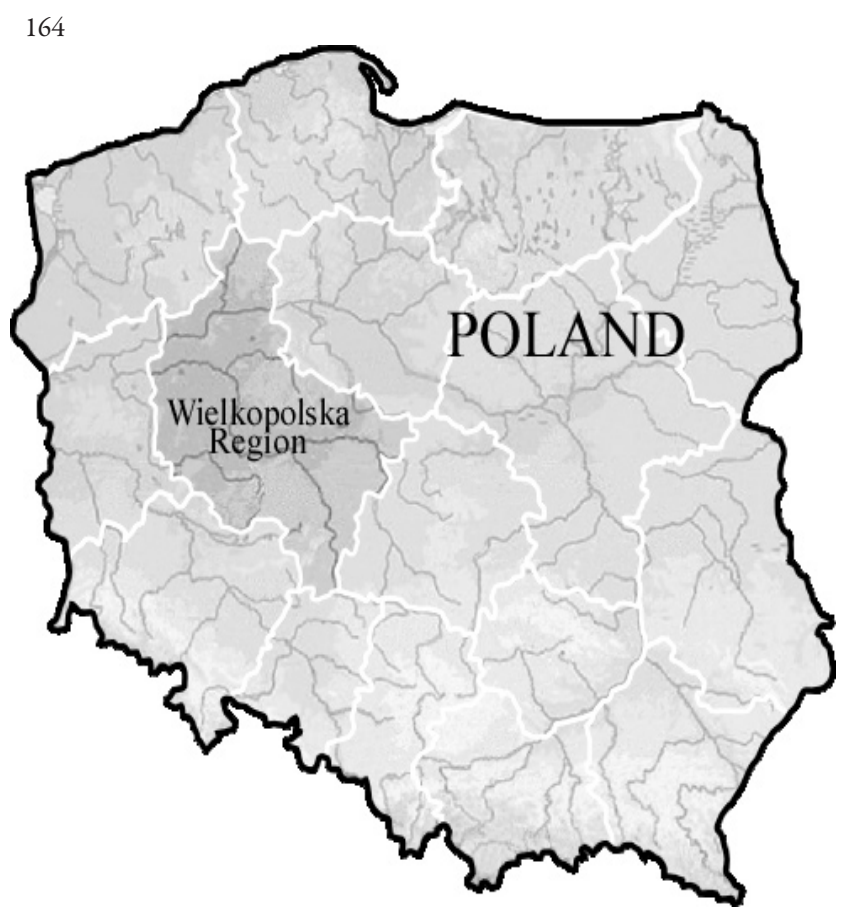

Fig. 1 Location of study area

Using JUICE software (Tichý, 2002), an initial TWINSPAN (Hill, 1979) hierarchical classification analysis was performed, which provided a preliminary picture of the similarities and differences between reléves. The data on these relevés were transcribed from the sevenpoint Braun-Blanquet scale into following values: $\mathrm{r}-0.1$, $+-0.5,1-5,2-18,3-38,4-63,5-88$. NCLAS software from the SYNTAX 5.0 package (Podani, 1993) conducted a dual classification: with respect to the presence of particular species and with respect to quantitativeness. Vegetation similarities in individual phytosociological reléves were determined with the aid of the Jaccard formula and the Ružičkova formula (Dzwonko, 1977). This was the basis for selecting four groups of reléves (each represented by 30 records). Every group had its own differential species which are used for valorisation of habitat, nature and utilization. The collection of 120 reléves was analysed using the CANOCO 4.5 software (Braak and Šmilauer, 2002). Data were processed with the assistance of PCA analysis, which makes it possible to determine major variability directions of the communities examined in accordance with the habitat gradient.

Site conditions of ryegrass meadows were determined by the phytoindication method (Ellenberg et al., 1992) which evaluated the following for each phytosociological reléve: moisture $(\mathrm{F})$, reaction $(\mathrm{R})$ and nitrogen content $(\mathrm{N})$. Moreover, for each plot the following parameters were determined using common laboratory methods: od,

- Soil moisture content-by the drier-gravimetric meth-

- Soil organic content-the gravimetric method involving sample roasting at a temperature of $600^{\circ} \mathrm{C}$ and calculation of weight losses,

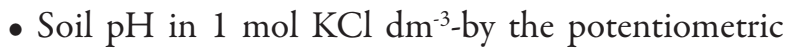
method: in mineral soils-by the Egner-Riehm method and in organic soils in $0.5 \mathrm{~mol} \mathrm{HCl} \mathrm{dm}^{-3}$,

- Content of available magnesium in mineral soils-by the Schachtschabel method and in organic soils in $0.5 \mathrm{~mol}$ $\mathrm{HCl} \mathrm{dm}{ }^{-3}$.

Trophism was described as combining the trophic factors $\left(\mathrm{Mg}-, \mathrm{P}_{2} \mathrm{O}_{5}^{-}, \mathrm{K}_{2} \mathrm{O}\right.$-content, $\mathrm{pH}$, the content of organic matter) and also one of Ellenberg's index-N-content.

Multifaceted natural valorisation concerned:

- diversity evaluation-the mean number of species in the reléve, botanical structure,

- natural evaluation-geographic-historical spectrum (Jackowiak, 1990), the proportion of life-groups (Zarzycki et al., 2002), ecological structure, natural value by the Oświt (2000) method,

- threatened evaluation-the proportion of species exhibiting the strongest expansiveness (Zarzycki et al., 2002).

Natural values were assessed by the Oświt method (2000), which was applied to assess the value of plant communities of wet areas and hydrogenic sites. It consists in ascribing each taxon a numerical value from 1 to 10 , depending on the species natural value. In this method, the most valuable species, protected and threatened are awarded the highest values, whereas common species not appearing at the hydromorphic site are given a value of 1 . The result was an arithmetical mean of the numerical value of the species which were recorded in reléve.

When performing utilization valorisation, the share of utilization groups as well as sward fodder value calculated according to Filipek (1973) were taken into account. The method developed by Filipek (1973) assigns each species an allotted number of fodder value from-3 to 10 . Negative numbers refer to poisonous species, numbers 0 and 1 are assigned to taxons characterised by the lowest fodder value and number 10-corresponds to the best species, such as Lolium perenne L. or Trifolium repens $\mathrm{L}$.

The species were assessed in accordance with the BraunBlanquet method with regard to the number of occurrences in relation to the total number of reléves of a given association, i.e. the constancy degree was determined and the mean area cover by the species in the community, i.e. the covering coefficient.

\section{Results and discussion}

The structure of ryegrass meadows situated in river valleys of lowland regions depends mainly on the site-its moisture conditions and trophism and, consequently, also on the utilization, i.e. the frequency of cutting and fertilisation. These aspects are also mentioned by Kojić et al. (2005), Kucharski (1999), and Rozbrojová et al. (2010). This led to variability in the internal structure of the floristic composition of the Arrhenatheretum elatioris phytoce- 
nosis and was applied as the basis for the identification of the following three sub-associations and one variant:

- Arrhenatheretum elatioris typicum

- Arrhenatheretum elatioris alopecuretosum pratensis

- Arrhenatheretum elatioris dactylietosum glomeratae

- Arrhenatheretum elatioris var. with Armeria maritima ssp. elongata.

Similar examples (sub-associations) which were an effect of ecological variability and vegetation dynamism also in the Molinio-Arrhenatheretea class as a whole are noted, e.g. Cirsietum rivularis, Angelico-Cirsietum oleracei, Filipendulo-Geranietum palustris (Balátová-Tuláčková et al., 1987), Polygono-Cirsietum palustris (Balátová-Tuláčková, 1974), Lolio-Cynosuretum, Trisetetum flavescentis, Alopecuretum pratensis, Molinietum medioeuropaeum communities (Kucharski and Michalska-Hejduk, 1994).

Typical, species-rich patches of Arrhenatheretum elatioris (A.e.) can be found relatively seldom. They occupy dry meadow sites or habitats which are moderately moist and utilised extensively. In the Wielkopolska Region, they develop primarily on mucky soils with sand frequently underlying at a depth of 0.4 to $0.6 \mathrm{~m}$ and with the water table situated at a level of $0.9 \mathrm{~m}$ in July. Soils are poor in the available forms of $\mathrm{Mg}$, $\mathrm{K}$ and $\mathrm{P}$ (Tab. 1). The highest constancy, apart from Arrhenatherum elatius (L.) P. Beauv. ex J. Presl and C. Presl is achieved here by Taraxacum officinale F. H. Wigg, Achillea millefolium L., Galium mollugo L. and Holcus lanatus L. (Tab. 2). The gradual disappearance from the agricultural landscape of semi-natural patches of Arrhenarberetum elatioris and their replacement by more productive monocultures of such grasses as Dactylis glomerata L. or Festuca pratensis Huds. was also reported by Brzeg and Wojterska (1996) and Dubiel et al. (1999).
Patches reminiscent of foxtail meadows, Arrhenatheretum elatioris alopecuretosum pratensis, begin to appear in places which are characterised by higher moisture and are richer in nutrients (Tab. 1). Their structure was found to contain increased proportions of species both from the Molinietalia order and the Phragmitetea class (Tab. 3) and the most constant components included: Arrhenatherum elatius (L.) P. Beauv. ex J. Presl and C. Presl, Alopecurus pratensis L., Rumex acetosa L. and Holcus lanatus L.

In the case of slightly elevated sites, on mineral soils and lower reaction as well as very low trophicity, patches with high proportions of Armeria maritima ssp. elongata Mill. Willd were recorded (Tab. 1). In their composition, increased proportions of species from the Festuco-Brometea and Koelerio glaucae-Corynephoretea canescentis classes were observed alongside numerous species characteristic for the Arrhenatheretalia order (Tab. 3).

On the other hand, Arrhenatheretum elatioris dactylietosum glomeratae phytocenoses were found to develop in the vicinity of large cattle farms, on strongly decomposed peats and mucks of moderate moisture content and a considerably higher site trophy (Tab. 1) caused by regular fertilisation. In comparison with the rest of the subassociations, a slightly higher total number of species was recorded in their sward accompanied by a simultaneously higher proportion of fodder grasses.

The PCA analysis of ecological indices performed here (Fig. 2) enabled illustration of the general site preferences of those sub-associations identified assigning phytosociological reléves with respect to Ellenberg's (1992) indicator numbers (F, R, N). The basic edaphic factor affecting the heterogeneity of ryegrass meadows might be moisture content (by Ellenberg's index). This factor differentiates firstly into Arrhenatheretum elatioris (A.e.) alopecuretosum

Tab. 1. Differentation of site conditions of the Arrhenatheretum elatioris

\begin{tabular}{|c|c|c|c|c|c|c|c|c|c|}
\hline \multirow{2}{*}{$\begin{array}{c}\text { Syntaxon of } \\
\text { Arrhenatheretum elatioris }\end{array}$} & \multirow{2}{*}{$\mathrm{F}$} & \multirow{2}{*}{$\mathrm{R}$} & \multirow{2}{*}{$\mathrm{N}$} & \multirow{2}{*}{$\begin{array}{l}\text { Actual moisture } \\
\text { [\%weight }]\end{array}$} & \multirow{2}{*}{$\begin{array}{l}\text { Soil pH [1 } \\
\text { mol KCl] }\end{array}$} & \multirow{2}{*}{$\begin{array}{l}\text { The content of } \\
\text { organic matter [\%] }\end{array}$} & $\mathrm{Mg}$ & $\mathrm{K}_{2} \mathrm{O}$ & $\mathrm{P}_{2} \mathrm{O}_{5}$ \\
\hline & & & & & & & \multicolumn{3}{|c|}{$\left[\mathrm{mg} \mathrm{kg}^{-1}\right]$} \\
\hline typicum & 5.6 & 6.6 & 5.9 & 37.6 & 5.6 & 18.3 & 16.5 & 54.9 & 68.5 \\
\hline dactylietosum glomeratae & 5.5 & 6.6 & 6.0 & 58.8 & 6.1 & 27.9 & 134.1 & 399.3 & 2005.5 \\
\hline alopecuretosum pratensis & 5.8 & 6.5 & 5.8 & 71.3 & 5.6 & 31.9 & 40.1 & 85.8 & 114.5 \\
\hline with Armeria maritima ssp. elongata & 5.3 & 6.2 & 5.4 & 15.1 & 4.8 & 4.2 & 9.2 & 22.8 & 26.5 \\
\hline
\end{tabular}

Tab. 2. Participation of characteristic species and number of species in reléve in Arrhenatherethum elatioris syntaxon

\begin{tabular}{|c|c|c|c|c|c|c|c|c|c|c|}
\hline \multirow{3}{*}{$\begin{array}{c}\text { Syntaxon of } \\
\text { Arrhenatheretum elatioris }\end{array}$} & \multicolumn{9}{|c|}{ Species characteristics for: (in \%) } & \multirow{3}{*}{$\begin{array}{l}\text { Number of species in } \\
\text { relevé (mean, range) }\end{array}$} \\
\hline & \multicolumn{3}{|c|}{ M-A } & \multirow[b]{2}{*}{ Phr. } & \multirow[b]{2}{*}{ Artem. } & \multirow[b]{2}{*}{ Stell. } & \multirow[b]{2}{*}{$\mathrm{K}-\mathrm{C}$} & \multirow[b]{2}{*}{ F-B } & \multirow[b]{2}{*}{ Other } & \\
\hline & Arrh. & Mol. & $\begin{array}{c}\text { Other } \\
\text { with M-A }\end{array}$ & & & & & & & \\
\hline typicum & 14.1 & 9.2 & 20.9 & 9.9 & 11.7 & 8.1 & 1.8 & 2.7 & 21.6 & $23(15-43)$ \\
\hline dactylietosum glomeratae & 15.7 & 8.3 & 24.2 & 3.7 & 10.2 & 15.6 & 1.9 & 1.9 & 18.5 & $18(11-30)$ \\
\hline alopecuretosum pratensis & 12.4 & 9.5 & 22.9 & 10.5 & 8.6 & 9.5 & 1.9 & 1.9 & 22.9 & $21(12-37)$ \\
\hline with Armeria maritima ssp. elongata & 16.7 & 7.8 & 23.5 & 5.9 & 7.8 & 6.9 & 5.9 & 2.9 & 22.5 & $22(13-35)$ \\
\hline
\end{tabular}

Note: M-A-Molinio-Arrbenatheretea; Arrh..-Arrhenatheretalia; Mol.-Molinietalia; Phr.-Phragmitetea; Artem.-Artemisietea vulgaris; Stell.-Stellarietea mediae;

K-C-Koeblerio glaucae-Corynephoretea canescentis; F-B-Festuco-Brometea. 
166

Tab. 3. Species with the highest constancy and cover index

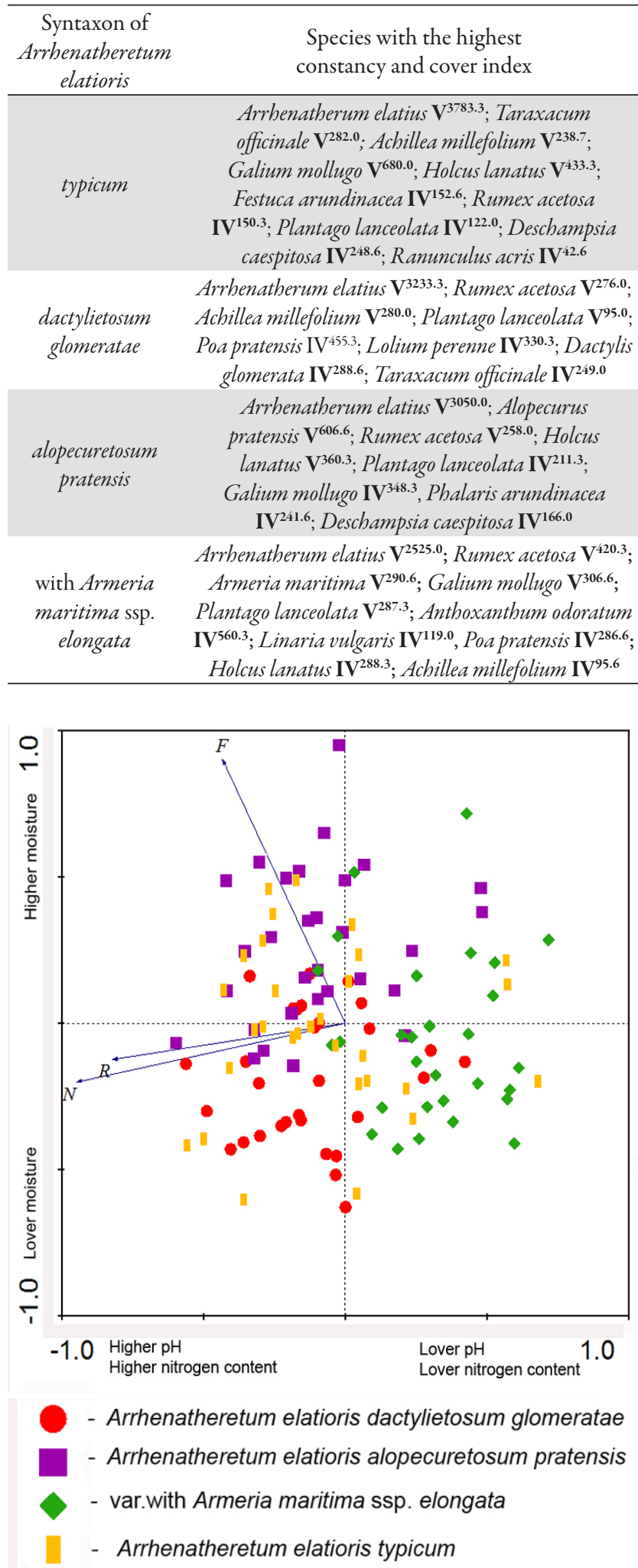

Fig. 2. Principal Components Analisis diagram (PCA) showing the main axes of variability in phytocenoses of the association Arrhenatheretum elatioris (Br.-Bl. 1925) Koch 1926 pratense and A.e. (variant with Armeria maritima ssp. elongata) sub-association, which clearly differ from each other, and secondly, the set of A.e. typicum and A.e. dactylietosum glomeratae reléves failed to form a distinct grouping. The group of A.e. alopecuretosum pratense reléves is distinctly visible as separate in the quarter for high $\mathrm{F}$ index values, whereas the A.e. variant with Armeria maritima ssp. elongata is distinct in the area of the diagram in which both the values of the $\mathrm{F}$ index as well as $\mathrm{R}$ and $\mathrm{N}$ indices are the lowest. These indices reflect site-plant community relationships, as confirmed by soil investigations (Tab. 1), i.e., including the higher moisture of soils occupied by the A.e. alopecuretosum pratense sub-association or low reaction and nitrogen availability of soils taken up by the variant with Armeria maritima ssp. elongata. The development of A.e. dactylietosum glomeratae, on the other hand, is most affected by soil reaction and nutrient availability, as evidenced by the grouping of the phytosociological reléves of this sub-association in the area of the diagram with the highest values of $\mathrm{R}$ and $\mathrm{N}$ indexes.

Therefore, the significant floristic variability of the Arrhenatheretum elatioris association observed is the outcome of both the diversification of sites occupied by this phytocenosis, but also reflected the method and intensity of utilization. In the case of fertilised and more frequently cut meadows (usually three times), the proportion of cultivated grasses increases, hence the A.e. dactylietosum glomeratae and A.e. alopecuretosum pratensis sward is characterised by the best fodder value. The variant with Armeria maritima ssp. elongata and Anthoxanthum odoratum that occupies the poorest sites contains many uncultivated grasses in its floristic composition as well as legumes which reduce sward fodder value (Tab. 4). Therefore, the species structure of ryegrass meadows depends greatly on human activity.

The considerable capability of the phytocenoses to adapt to various site conditions is further corroborated by distinct taxon dynamism as expressed by more than a $40 \%$ share of species of high expansion capability. This becomes particularly apparent in sites where the floristic composition is modified to a lesser degree by utilization-A.e. variant with Armeria maritima ssp. elongata. In the biological spectrum, hemicryptophytes characteristic for the temperate zone are dominant and the increased proportion of therophytes in the sward of the A.e. dactylietosum glomeratae sub-association can probably be attributed to intensively utilization and the possibility to spread species from neighbouring fields (Tab. 5).

On study plots, ruderal and segetal species which were frequently alien to hydrogenic sites were found. At the present time, this is reflected in the very low value of the valorisation index calculated according to Oświt (2000), classifying patches of ryegrass meadows as naturally poor. 
Tab. 4. Influence on useful groups and fodder value score (FVS)

\begin{tabular}{cccccccc}
\hline $\begin{array}{c}\text { Syntaxon of } \\
\text { Arrhenatheretum elatioris }\end{array}$ & Grasses & Legumes & Sedges & $\begin{array}{c}\text { Herbs and } \\
\text { weeds }\end{array}$ & $\begin{array}{c}\text { Proportion of valuable } \\
\text { species (folder grasses } \\
\text { + legumes) [\%] }\end{array}$ & $\begin{array}{c}\text { FVS } \\
\text { (Fodder Value } \\
\text { Score) }\end{array}$ \\
\hline Typicum & 71.0 & 0.7 & 0.3 & 28.0 & 60.4 & 6.90 \\
Dactylietosum glomeratae & 74.8 & 0.7 & 0.1 & 24.4 & 69.1 & 7.46 \\
Alopecuretosum pratensis & 76.8 & 0.4 & 0.9 & 21.9 & 66.5 & 7.16 \\
with Armeria maritima & 72.6 & 0.9 & 0.4 & 26.1 & 51.9 & 6.37 \\
\hline
\end{tabular}

Tab. 5. Natural values of the Arrhenetheretum elatioris

\begin{tabular}{|c|c|c|c|c|c|c|c|c|c|c|}
\hline \multirow[b]{2}{*}{$\begin{array}{c}\text { Syntaxon of } \\
\text { Arrhenatheretum elatioris }\end{array}$} & \multicolumn{4}{|c|}{$\begin{array}{c}\text { Geographic-historical } \\
\text { spectrum [\%] }\end{array}$} & \multirow{2}{*}{ 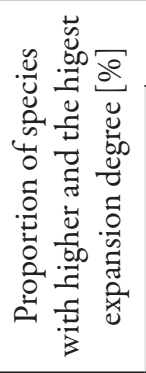 } & \multicolumn{3}{|c|}{ Raunkiaer'slife forms [\%] } & \multicolumn{2}{|c|}{ Natural value } \\
\hline & 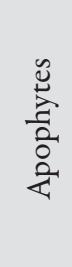 & 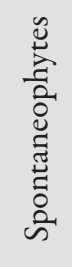 & 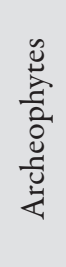 & 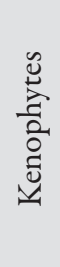 & & 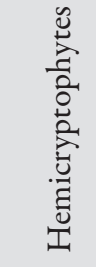 & 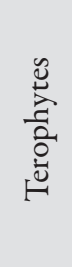 & $\frac{\vec{\Delta}}{\Delta}$ & 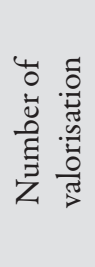 & $\frac{\mathscr{y}}{\tilde{J}}$ \\
\hline Typicum & 71.2 & 18.9 & 8.1 & 1.8 & 41.4 & 69.4 & 14.4 & 16.2 & 2.0 & small \\
\hline Dactylietosum glomeratae & 71.3 & 11.1 & 14.8 & 2.8 & 43.5 & 59.3 & 23.1 & 17.6 & 1.9 & small \\
\hline Aalopecuretosum pratensis & 72.4 & 18.1 & 7.6 & 1.9 & 45.7 & 63.8 & 16.2 & 20.0 & 2.1 & small \\
\hline with Armeria maritima & 78.4 & 13.7 & 5.9 & 2.0 & 47.1 & 68.6 & 17.6 & 13.7 & 1.8 & under small \\
\hline
\end{tabular}

However, in the case of typical sites, these are among the most beautiful flowering meadows in this landscape.

The development of meadow communities depends, to a great extent, on human activity as well as on site conditions, which are also frequently modified by man. Hence, the syntaxonomic position of some phytocenosis and their lower units is frequently widely discussed as evidenced by characteristic ryegrass meadows. This wide ecological scale of the association provides a basis for it to be treated as a central unit-Arrhenatheretum medioeuropaeum (Ilianič and Šegulja, 1983; Ilianič and Vučkowić, 1982; Ullman et al., 1990) within the framework of which, a number of lower sub-associations and variants exist. The central units are a result of the higher constancy of characteristic species for alliance than association (Dierschke, 1981; Kopecký and Hejný, 1974)

Similar difficulties with the classification of seminatural communities into the phytosociological system are encountered in the case of the Alopecuretum pratensis association (Matuszkiewicz, 2008). In the work of some researchers, this is included in the Arrhenatheretalia order as the wettest form of the Arrhenatheretum elatioris association (Grynia, 1987), while in the work of others, it is treated as a separate association in the ArrhenatherionAlopecuretum pratensis alliance (Kucharski and Michalska-Hejduk, 1994) or as Ranunculo repentis-Alopecuretum pratensis (Valev et al., 2011), sometimes as Poo-Alopecuretum pratensis (Kojić et al., 2005). Recently, it has usually been treated as a central association in the Alopecurion of the Molinietalia order (Alma et al., 2008; Matuszkiewicz, 2008). Meadows dominated by Holcus lanatus (Blažková,
1992) cause also serious problems with unequivocal classification. Most researchers include Holcus lanatus community in the Calthion alliance (Kovár., 1981; Kryszak, 2001), whereas Duchoslav (1997) and Kucharski (1999) place it in Alopecurion pratensis. Sometimes velvet grass is also classified into the Arrhenatherion elatioris alliance (Kováčová, 1976).

The multiplicity and dynamism of factors affecting the vegetation cover both in Poland as well as in Europe as a whole makes it necessary to widen our knowledge of the structure of plant communities and directions of transformations taking place inside them. At the present time, it is also very important to monitor these changes, primarily in order to undertake appropriate action to maintain the high biodiversity of seminatural meadow phytocenoses (Dierschke, 1999b; Elmore and Mustard, 2003; Ford, 1997; Isselstein et al., 2005; Kopecký and Hejný, 1974; Looy et al., 2006; Peeters and Janssens, 1998; Plantureux et al., 2005).

\section{Conclusions}

All factors affecting ryegrass meadows exert an influence on their extraordinary heterogeneity. However, the development of lower phytosociological units in lowland areas depends mainly on site moisture and soil nutrient availability which, in turn, is influenced by fertilization. Both soil aridity and a shortage of nutrients result in the loosening of the sward and the incursion of synantroppic species, as well as short-lived sand and steppe species which are better adapted to altered edaphic conditions. 
168

The abundance of species and the natural value of the $A r$ rhenatheretum elatioris association all depend primarily on utilization intensity and are inversely proportional to sward fodder value.

\section{References}

Alma N, Niculescu M, Imbrea I (2008). Alluvial and lovland hay meadows in the median basin of the River Timis (South-Western Romania). Bulletin UASVM, Agriculture 65(1):176-181.

Balátová-Tuláčková E (1974). Zur phytozönologischen Bewertun der Feuchtwiesen mit Cirsium palustre in Nordwestböhmen. Folia Geobot Phytotax 9:153-166.

Balátová-Tuláčková E, Venanzoni R, Vaněčková L (1987). Wiesen-und Hochstauden-Gesellschaften im Landschaftsschutzgebiet Moravský kras. Tuxenia 7:215232.

Blažková D (1992). Was is das Holcetum lanati? Preslia 64:5961.

ter Braak CJF, Šmilauer P (2002). CANOCO Reference Manual and CanoDraw for Windows User's Guide: Software for Canonical Community Ordination (version 4.5). Section on permutation methods. Microcomputer Power (Ithaca NY, USA) 500 p.

Brzeg A, Wojterska M (1996).Systematic review of Wielkopolska Region plant communities with threatened value assessment. Bad Fizjogr Nad Polską Zach, Ser B 45:7-40 (In Polish).

Dierschke H (1981) Synataxonomiche Gliederung der Bergwiesen Mitteleuropas (Polygono-Trisetion), 311-341 p. In: Dierschke H (red.) Synataxonomie. Ber Int Symp Int Vereinig Vegetationsk Rinteln.

Dierschke H (1994). Syntaxonomical survey of MolinioArrhenatheretea in Central Europe. Colloq Phytocos XXIII: 386-399.

Dierschke H (1999a). Klassyfikation und systematiche Ordnung von Pflanzengesellschaften. Ber Reich Tüxen-Ges 11:19-38.

Dierschke H (1999b). Short survey of Arrhenatheretalia grassland in Germany. Ann Bot 57:7-14.

Dubiel E, Stachurska A, Gawroński S (1999). Non-forest plant communities Magura National Park (Beskid Niski Mts). Prace Bot UJ/Bot Papers 33:1-60.

Duchoslav M (1997). The present state of meadow vegetation (Molinio-Arrhenatheretea) in the Morava river floodplain (Hornomoravský úval area). Zpr Čes Bot Společ Mater 15:131-176.

Dzwonko Z (1977). The use numerical classification in phytosociology. Fragm Flor Geobot 23:327-343 (In Polish).

Ellenberg H, Weber H, Dull R, Wirth V, Werner W, Paulissner D (1992). Zeigerwerte der Pflanzeb in Mitteleuropa. Scr Geobot 18:5-258.

Elmore AJ, Mustrad SJ (2003). Regional patterns of plant community response to changes in water: Owens Valley, Califorina Ecol Appl 12(2):443-460.

Filipek J (1973). The proposal for the classification of meadow and pasture plants on the basis of fodder value scores. Post Nauk Roln 4:58-69 (In Polish).

Ford MA (1997). The Arrhenatheretum on set-aside at Aldroughty. Elgin Bot J Scot 49(1):67-73.

Grynia M (1987). Geobotanical characteristics and economic importance of rygrass meadows in Wielkopolska. Zesz Prob Post Nauk Roln 308:81-86 (In Polish).

Hill M (1979). Decorana a Fortran Program for Detrerded Correspondence Analisysis and Reciprocal Averaging. Ecology and Systematics. Cornell University, Ithaca, New York, $52 \mathrm{p}$.

Ilianič L, Vučkowić R (1982). Steppensalbei-Glatthaferwiesen In der Umgenbung von Sečanj in der Vojvodina. Acta Bot Croat 41:93-102.

Ilianič L, Šegulja N (1983). Phytozönologische und Ökologische Untersuchungen der glatthaferiesen in der Podravina (Nordkroatien). Acta Bot Croat 42:63-82.

Isselstein J, Jeangros B, Pavlu V (2005). Agronomic aspects of biodiversity target es management of temporate garsslands in Europe-a review. Agron Res 3(2):139-155.

Jackowiak B (1990). Anthropogenic changes of vacsular flora in Poznan. Wyd Nauk UAM 42:1-242 (In Polish).

Kojić M, Mrfat-Vuelić S, Dordević-Milošević S (2005). Basic phytocenological and economical characteristic of meadows and pastures of Serbia. Biotechnol An Husband 21(56):187-191.

Kopecký K, HejnýS (1974). A new approach to the classification of anthropogenic plant communities. Vegetatio 36:17-20.

Kováčová M (1976). Asociacia Holcetum lanati (Issler 1936) em. Passarge 1964 v údolí rieky Krupinice. Biologia 31:795800.

Kovár P (1981). The Grassland Communities of the Southeastern Basin of the Labe River. 1. Syntaxonomy. Fol Geobot Phytotax 43 p.

Kryszak A (2001). Floristic diversity of meadow and pastures associations of the Molinio-Arrhenatheretea R. Tx. 1937 class in Wielkopolska from the point of viev of their economic value. Rocz. AR Poznań, Rozprawy Naukowe 182 p. (In Polish).

Kucharski L (1999). Vegetation of the Central Polish meadows and their changes in the twentieth century. Wyd Uniw Łódzkiego 168 p. (In Polish).

Kucharski L, Michalska-Hajduk D (1994). Overview of associations from Molinio-Arrhenatheretea class found in Poland. Wiad Bot 38(1-2):95-104 (In Polish).

Looy KV, Honnay O, Pedroli B, Muller S (2006). Order and disorder in the river continuum: the contribution of continuity and connectivity to floodplain meadow biodiversity. J Biogeography 33(9):1615-1627.

Matuszkiewicz W (2008). A quide to identification of 
plantcommunities of Poland. Wyd Nauk PWN: Warsaw, Vademecum Geobotanicum 3. PWRiL Warszawa 537 p. (In Polish).

Mucina L, Grabherr G, Ellmauer T, Wallnöfer S (eds.) (1993). Die Pflanzengesellschaften Österreichs. 1-3. Gustav Fischer Jena.

Oświt J (2000). The method of valuation of natural wetlands and the results of its application to selected objects. IMUZ, Mat. Inform 35:1-36 (In Polish).

Peeters A, Jonssens F (1998). Species-rich grasslands: diagnostic, restorations and use in intensive livestock production systems. Grassld Sci Eur 3:375-393.

Podani J (1993). SYN-TAX-pc. Computer Programs For Mulivariate Data Analysis In Ecology And Systematics. Ver. 5.0-User's Guide. Scientia Publishing 351 p.

Plantureux S, Peeters A, McCracken D (2005). Biodiversity in intensive grasslands: Effect of management, improvement and challenges. Agron Res 3(2):153-164.

Rozbrojová Z, Hájek M, Hájek O (2010). Vegetation diversity of mesic meadows and pastures in the West Carpathians. Preslia 82:307-332.

Sykora KV, Krogt G van der; Rademakers J (1990). Vegetation change on embankments in the south-western part of The Netherlands under the influence of different management practices (in particular sheep grazing). Biol Conserv 52 (1):49-81.

Szafer W, Zarzycki K (1977). Polish flora I Wyd Nauk PWN 615 p. (In Polish).
Ullman I, Heindel B, Schug B (1990). Naturräumliche Gliederung der Vegetation auf Strassenbegleitfächen im westlichen Unterfranken. Tüexenia 10:197-222.

Tichý L (2002). JUICE, software for vegetation classification. J Veget Sci 13:451-453.

Valev N, Apostolova I, Rozbrojová Z (2011). Alliance Arrhenatherion elatioris in West Bulgaria. Phytol Baltanica 17(1):67-78.

Vintu V, Samuil C, Rotar I, Moisuc A, Razec I (2011). Influence of the Management on the Phytocoenotic Biodiversity of Some Romanian Representative Grassland Types. Not Bot Horti Agrobo 39(1):119-12.

Weigelt A, Weisser WW, Buchmann N, Scherer-Lorenzen M (2009). Biodiversity for multifunctional grasslands: equal productivity in high-diversity low-input and low-diversity high-input systems. Biogeosci 6(8):1695-1706.

Zarzycki K, Trzcińska-Tacik H, Różański W, Szeląg Z, Wołek J, Korzeniak U (2002). Ecological indicator values of vascular plants of Poland. W. Szafer Institute of Botany, Polish Academy of Science: Kraków 183 p.

Zarzycki J, Kopeć M, Bedla D (2011). Evaluation of diversity of grassland habitats in the Pradziejowa Range (Beskid Sądecki Mountains) using the phytoindication metod. Fragm Agron 28(1):115-123

Żyszkowska M (2007). Communities of the order Arrhenatheretalia as an indicator of habitat conditions in the Bystrzyca Dusznicka Valley. Water Environ Rural Areas 7(2b):205218 (In Polish). 